\title{
The size of surface microstructures as an osteogenic factor in calcium phosphate ceramics
}

Citation for published version (APA):

Zhang, J., Luo, X., Barbieri, D., Barradas, A. M. C., de Bruijn, J. D., Van Blitterswijk, C. A., \& Yuan, H. (2014). The size of surface microstructures as an osteogenic factor in calcium phosphate ceramics. Acta Biomaterialia, 10(7), 3254-3263. https://doi.org/10.1016/j.actbio.2014.03.021

Document status and date:

Published: 01/07/2014

DOI:

10.1016/j.actbio.2014.03.021

Document Version:

Publisher's PDF, also known as Version of record

Document license:

Taverne

Please check the document version of this publication:

- A submitted manuscript is the version of the article upon submission and before peer-review. There can be important differences between the submitted version and the official published version of record.

People interested in the research are advised to contact the author for the final version of the publication, or visit the DOI to the publisher's website.

- The final author version and the galley proof are versions of the publication after peer review.

- The final published version features the final layout of the paper including the volume, issue and page numbers.

Link to publication

\footnotetext{
General rights rights.

- You may freely distribute the URL identifying the publication in the public portal. please follow below link for the End User Agreement:

www.umlib.nl/taverne-license

Take down policy

If you believe that this document breaches copyright please contact us at:

repository@maastrichtuniversity.nl

providing details and we will investigate your claim.
}

Copyright and moral rights for the publications made accessible in the public portal are retained by the authors and/or other copyright owners and it is a condition of accessing publications that users recognise and abide by the legal requirements associated with these

- Users may download and print one copy of any publication from the public portal for the purpose of private study or research.

- You may not further distribute the material or use it for any profit-making activity or commercial gain

If the publication is distributed under the terms of Article $25 \mathrm{fa}$ of the Dutch Copyright Act, indicated by the "Taverne" license above, 


\title{
The size of surface microstructures as an osteogenic factor in calcium phosphate ceramics
}

\author{
Jingwei Zhang ${ }^{\mathrm{a}, \mathrm{b}}$, Xiaoman Luo ${ }^{\mathrm{c}, \mathrm{d}}$, Davide Barbieri ${ }^{\mathrm{d}}$, Ana M.C. Barradas ${ }^{\mathrm{e}}$, Joost D. de Bruijn ${ }^{\mathrm{c}, \mathrm{d}, \mathrm{f}}$, \\ Clemens A. van Blitterswijk ${ }^{\mathrm{a}}$, Huipin Yuan ${ }^{\mathrm{a}, \mathrm{d}, *}$
}

a Department of Tissue Regeneration, MIRA Institute for Biomedical Technology and Technical Medicine, University of Twente, P.O. Box 217, 7500AE Enschede, The Netherlands ${ }^{\mathrm{b}}$ Key Laboratory of Advanced Technologies of Materials, Ministry of Education, School of Materials Science and Engineering, Southwest Jiaotong University, Chengdu, People's Republic of China

${ }^{\mathrm{c}}$ Department of Biomaterials Science and Technology, MIRA Institute for Biomedical Technology and Technical Medicine, University of Twente, P.O. Box 217, 7500AE Enschede, The Netherlands

${ }^{\mathrm{d}}$ Xpand Biotechnology BV, Bilthoven, The Netherlands

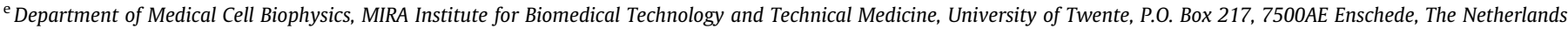

${ }^{\mathrm{f}}$ School of Engineering and Materials Science (SEMS), Queen Mary University of London, London E1 4NS, UK

\section{A R T I C L E I N F O}

\section{Article history:}

Received 4 November 2013

Received in revised form 13 March 2014

Accepted 20 March 2014

Available online 27 March 2014

\section{Keywords}

Calcium phosphate

Microstructure

Surface topography

Mesenchymal stem cell

Osteogenesis

\begin{abstract}
A B S T R A C T
The microporosity of calcium phosphate (CaP) ceramics has been shown to have an essential role in osteoinduction by CaP ceramics after ectopic implantation. Here we show that it is not the microporosity but the size of surface microstructural features that is the most likely osteogenic factor. Two tricalcium phosphate (TCP) ceramics, namely TCP-S and TCP-B, were fabricated with equivalent chemistry and similar microporosity but different sizes of surface microstructural features. TCP-S has a grain size of $0.99 \pm 0.20 \mu \mathrm{m}$ and a micropore size of $0.65 \pm 0.25 \mu \mathrm{m}$, while TCP-B displays a grain size of $3.08 \pm 0.52 \mu \mathrm{m}$ and a micropore size of $1.58 \pm 0.65 \mu \mathrm{m}$. In vitro, both cell proliferation and osteogenic differentiation were significantly enhanced when human bone marrow stromal cells were cultured on TCP-S without any osteogenic growth factors, compared to TCP-B ceramic granules. The possible involvement of direct contact between cells and the TCP ceramic surface in osteogenic differentiation is also shown with a trans-well culture model. When the ceramic granules were implanted in paraspinal muscle of dogs for 12 weeks, abundant bone was formed in TCP-S ( $21 \pm 10 \%$ bone in the available space), whereas no bone was formed in any of the TCP-B implants. The current in vitro and in vivo data reveal that the readily controllable cue, i.e. the size of the surface microstructure, could be sufficient to induce osteogenic differentiation of mesenchymal stem cells, ultimately leading to ectopic bone formation in calcium phosphate ceramics.
\end{abstract}

(C) 2014 Acta Materialia Inc. Published by Elsevier Ltd. All rights reserved.

\section{Introduction}

The need for reconstruction of massive and segmental bone defects frequently arises from skeletal disease, congenital malformations, infection, trauma and post-cancer ablative surgery [1]. Currently, autografts, allografts and synthetic materials are considered for bone regeneration [2-4]. For decades, autogenous bone graft has been the gold standard for bone repair; however, the amount of harvestable autografts is limited. Allografts, which provide much larger amounts of tissue than autografts, may carry

* Corresponding author at: Xpand Biotechnology BV, Professor Bronkhorstlaan 10-d, 3723 MB Bilthoven, The Netherlands. Tel.: +31 30 2297292; fax: +31 30229 7299 .

E-mail address: h.yuan@utwente.nl (H. Yuan). the unpredictable risks of immunological reaction and disease transmission [5]. Therefore, increasing attention has been paid to developing synthetic materials with similar performances to autologous bone.

Calcium phosphate ( $\mathrm{CaP}$ ) ceramics are nowadays widely used as bone graft substitutes because their chemical composition resembles that of bone mineral and they have excellent biocompatibility and bioactivity [6-8]. The repair of non-critical-sized bone defects can be achieved with osteoconductive CaP ceramics, which can lead to bone ingrowth from the surrounding host bone bed. However, to repair critical-sized bone defects, osteoinductive materials that could induce mesenchymal stem cells (MSCs) to form bone (i.e. after an ectopic implantation) are necessary. A specific group of CaP ceramics has been reported to be osteoinductive in several animal models after heterotopic/ectopic implantation of 
the materials (e.g. subcutaneously or intramuscularly) [9]. It has also been shown that materials with higher osteoinductive potential could heal non-critical-sized defects faster $[10,11]$. Furthermore, osteoinductive CaP ceramics could perform similarly to autologous bone grafts and recombinant human bone morphogenetic protein 2 in repairing critical-sized bone defects [12].

Osteoinduction of CaP ceramics is material dependent. Of the factors involved in osteoinduction, chemical composition [11-13], macrostructural properties $[9,14]$ and microporosity (i.e. the volume percentage of pores smaller than $10 \mu \mathrm{m}$ ) [15-17], microporosity has been shown to be of great importance. Previous studies have shown that microporous hydroxyapatite (HA) ceramics could induce bone formation after subcutaneous [18] and intramuscular [19] implantations in dogs, while no bone was formed in those materials lacking microporosity. It has been also reported that the osteoinductive potential of CaP ceramics increased with increasing microporosity $[12,20]$.

It has been suggested, but not demonstrated, that the presence of micropores in CaP ceramics increases the surface area, thereby enhancing the local concentration of growth factors, including osteoinductive bone morphogenetic proteins (BMPs), which may induce osteogenic differentiation of MSCs to form bone [12,1921]. If the surface area, and thus protein adsorption, plays a role in osteoinduction by CaP ceramics, changing the microstructural properties by altering the size of the micropores would change their osteoinductive potential.

Besides the possible role of protein adsorption in osteogenic differentiation of MSCs, an increasing number of studies have shown that MSCs could respond to extracellular matrix signals via topographical cues and tend towards osteogenic differentiation [22-24]. The change of microstructural features' dimensions alters the surface properties, which, at a certain scale and with specific topographies, may initiate the osteogenic differentiation of stem cells [25]. In addition, the possible role of ion release from CaP ceramics in osteogenic differentiation of MSCs cannot be ignored. The resulting change in the surface area will affect ion exchanges (e.g. calcium ion) with the surroundings, ultimately influencing the osteogenic response of the cells [26].

Taking together the possible roles of protein adsorption, surface topography and ion exchange in osteogenic differentiation of MSCs, we hypothesized that altering the surface microstructure size will influence the osteoinduction potential of $\mathrm{CaP}$ ceramics. To test this hypothesis, we prepared two tricalcium phosphate ceramics (TCP-S and TCP-B) with similar microporosity but with various micropore sizes and evaluated their osteoinductive potential in vitro with human bone marrow stromal cells (hBMSCs) and in vivo in a canine ectopic model.

\section{Materials and methods}

\subsection{CaP ceramics}

\subsubsection{Preparation of TCP ceramics with various microstructure dimensions}

$\mathrm{CaP}$ powders were synthesized by mixing calcium hydroxide (Fluka) and phosphoric acid (Fluka) at a $\mathrm{Ca} / \mathrm{P}$ ratio of 1.50 . TCP powders allowing large (TCP-B) or small (TCP-S) grains in the final ceramics were prepared by controlling the reaction rates. $\mathrm{H}_{3} \mathrm{PO}_{4}$ solution was directly poured into a $\mathrm{Ca}(\mathrm{OH})_{2}$ suspension to get TCP-B, while $\mathrm{H}_{3} \mathrm{PO}_{4}$ solution was added dropwise to a $\mathrm{Ca}(\mathrm{OH})_{2}$ suspension to get TCP-S. The powders were then foamed with diluted $\mathrm{H}_{2} \mathrm{O}_{2}$ (1\%) and porogen (i.e. wax particles) to obtain porous green bodies. TCP-S ceramic was obtained by sintering the porous green bodies at $1050{ }^{\circ} \mathrm{C}$ for $8 \mathrm{~h}$ as the target, while TCP-B porous green bodies were sintered at different temperatures (1050, 1100 and $1150{ }^{\circ} \mathrm{C}$ ) for $8 \mathrm{~h}$ in order to get target TCP-B ceramic having porosities (both total porosity and microporosity) close to those of TCP-S, as measured by mercury intrusion porosimetry (Auto Pore IV 9500, Micromeritics, Monchengladbach, Germany).

TCP-S and TCP-B granules, 1-2 $\mathrm{mm}$ in size, were prepared from the sintered porous ceramic bodies and ultrasonically cleaned, first with acetone, then with $70 \%$ ethanol and finally with demineralized water. The granules were then dried at $80^{\circ} \mathrm{C}$ and finally sterilized with gamma irradiation ( $25 \mathrm{kGy}$, Isotron, Netherland BV, Ede, The Netherlands).

\subsubsection{Physico-chemical properties of TCP ceramics}

The chemical composition and crystal structure of the TCP granules were determined by X-ray diffraction (XRD; Rigaku, Tokyo, Japan). Grain and micropore size were studied with an environmental scanning electron microscope (XL30, ESEMFEG, Philips, Eindhoven, The Netherlands) in the secondary electron mode and quantified with Image (v1.43u, NIH, USA). Grains and micropores were randomly selected from an image and the vertical lengths crossing the centre of each grain and micropore were considered to be the grain and pore size, respectively. Data of total porosity (i.e. the volume percentage of pores), microporosity and micropore size distribution of the porous ceramics were obtained by mercury intrusion. The specific surface area was analyzed with the Brunauer-Emmett-Teller method (BET; ChemBET monopoint Physisorption, QuanTachrome GmbH, Germany).

\subsubsection{Protein adsorption of the ceramics}

To demonstrate the influence of microstructure size on the protein adsorption, $100 \mathrm{mg}$ of TCP-S and TCP-B granules was immersed in $2 \mathrm{ml}$ of basic culture medium (BM), consisting of minimal essential medium-alpha ( $\alpha$-MEM; Gibco) supplemented with $10 \%$ fetal bovine serum (Lonza), $100 \mathrm{U} \mathrm{ml}^{-1}$ penicillin and $100 \mu \mathrm{g} \mathrm{ml}^{-1}$ streptomycin (Gibco), $2 \mathrm{mM}$ L-glutamine (Gibco) and $0.2 \mathrm{mM}$ L-ascorbic acid 2-phosphate (Sigma-Aldrich) and incubated at $37{ }^{\circ} \mathrm{C}$ in a humid atmosphere with $5 \% \mathrm{CO}_{2}$ for 1 and 4 days. After washing three times with PBS, $0.2 \mathrm{ml}$ of RIPA buffer (Thermo scientific) was added to each sample and kept at $4{ }^{\circ} \mathrm{C}$ for $10 \mathrm{~min}$. Thereafter the amount of protein detached from the ceramics into the RIPA buffer was measured with the QuantiPro ${ }^{\mathrm{TM}}$ BCA Assay Kit (Sigma, The Netherlands) following the manufacturer's instructions and fluorescence was measured with a spectrophotometer (Anthos Zenyth 3100, Anthos Labtec Instruments GmbH, Salzburg, Austria) at $620 \mathrm{~nm}$. A calibration curve was prepared using standard BSA solutions. Three samples were used per material $(n=3)$ and the protein content was expressed as mean \pm SD.

\subsubsection{Ion release from the ceramics}

To evaluate the influence of microstructure size on the ion release, $100 \mathrm{mg}$ of the TCP granules was immersed in $2 \mathrm{ml}$ of BM and incubated at $37{ }^{\circ} \mathrm{C}$ in a humid atmosphere with $5 \% \mathrm{CO}_{2}$ for 1 , 4, 7 and 14 days. Calcium concentration in the culture medium was measured with a QuantiChrom ${ }^{\mathrm{TM}}$ Calcium assay kit (BioAssay, USA) and compared to the control (i.e. BM without samples) following the manufacturer's guidelines. Absorbance measurements were performed with a spectrophotometer at $620 \mathrm{~nm}$. The calcium concentration was expressed as mean $\pm \mathrm{SD}$, measured through standard calibration curves. Three samples were used per material $(n=3)$. Meanwhile the ceramic particles were collected and subjected to XRD analysis and scanning electron microscopy (SEM) evaluation of possible surface changes.

\subsection{Cell culture}

\subsubsection{Isolation and expansion of $h B M S C S$}

Bone marrow aspirates $(5-20 \mathrm{ml})$ were obtained from a donor (69 years old, female) with written informed consent. In brief, 
aspirate was resuspended using $20 \mathrm{G}$ needles, plated at a density of $5 \times 10^{5}$ cells $\mathrm{cm}^{-2}$ and cultured in proliferation medium containing $\mathrm{BM}$ and basic fibroblast growth factor (Instruchemie, The Netherlands, $1 \mathrm{ng} \mathrm{ml}^{-1}$ ). Cells were expanded at $37^{\circ} \mathrm{C}$ in a humid atmosphere with $5 \% \mathrm{CO}_{2}$. The medium was refreshed twice a week and the cells were subcultured until $80 \%$ confluence.

\subsubsection{Cell culture on TCP ceramics}

To study the influence of microstructure size on proliferation, osteogenic differentiation and bone-related gene expression, hBMSCs were cultured on TCP granules. For this, $100 \mathrm{mg}$ of TCP-S and TCP-B granules was soaked in BM for at least $4 \mathrm{~h}$ before cell seeding. The TCP granules were placed in the square wells of polystyrene plates. A cell suspension of $150 \mu \mathrm{l}$ of hBMSCs at passage 3 were seeded onto the materials at a seeding density of 3,750,000 cells $\mathrm{ml}^{-1}$. Cells were allowed to attach for $4 \mathrm{~h}$, after which $2 \mathrm{ml}$ of BM was slowly added to each sample. The medium was refreshed every 3 days $(2 \mathrm{ml})$. For stereomicroscopic observation and cell proliferation assay, samples were harvested at days 1, 7, 14 and 21; for osteogenic differentiation assay, samples were harvested at days 7, 14 and 21; for bone related gene expression, samples were harvested at days 4, 7 and 14; and for BMP-2 production, samples were harvested at days 2 and 4 .

\subsubsection{Trans-well culture}

TCP-S and TCP-B granules $(100 \mu \mathrm{g})$ were loaded onto a transwell membrane fitted to a 24-well plate and soaked in BM for at least $4 \mathrm{~h}$ before cell seeding. Third passage hBMSCs were seeded at a density of 25,000 cells per well and cultured in BM under a 3 day refreshment regime $(2 \mathrm{ml})$. To evaluate cell proliferation and osteogenic differentiation, samples were harvested at days 1 , 4, 7 and 14.

\subsubsection{Stereomicroscopy}

Cell distribution on the granules was observed with a light microscope (E600, Nikon, Japan) equipped with a KL 1500 LCD camera after fixing with $10 \%$ neutral formalin and staining with $1 \%$ methylene blue.

\subsubsection{Cell proliferation and osteogenic differentiation assays}

Cell proliferation was analyzed with a DNA assay (CyQuant Cell Proliferation Assay kit, Sigma, The Netherlands), while osteogenic differentiation was measured with an alkaline phosphatase (ALP) assay (CDP-star assay kit, Roche). Prior to the analyses, the samples were rinsed three times with PBS and stored at $-20{ }^{\circ} \mathrm{C}$ until further use. A $1 \mathrm{ml}$ volume of lysis buffer (prepared according to manufacturer's instructions of CyQuant Cell Proliferation Assay kit instructions) was added onto each sample, followed by two cycles of freezing and thawing at $-20^{\circ} \mathrm{C}$ and room temperature, respectively.

After lysis, the total DNA was measured by incubating $100 \mu \mathrm{l}$ of the lysed sample in the dark at room temperature for $1 \mathrm{~h}$. The samples were then incubated with $100 \mu \mathrm{l}$ of CyQuant GR dye at room temperature for $15 \mathrm{~min}$. Fluorescence was measured using a spectrophotometer (Victor, Perkin Elmer) at an excitation wavelength of $480 \mathrm{~nm}$ and an emission wavelength of $520 \mathrm{~nm}$. The DNA content of cells was calculated through a standard DNA curve. Three samples were used per material $(n=3)$.

ALP activity was measured according to the manufacturer's instructions. Briefly, $40 \mu \mathrm{l}$ of CDP star substrate was incubated with $10 \mu \mathrm{l}$ of cell lysate for $20 \mathrm{~min}$, after which luminescence was measured using a spectrophotometer (Victor). The ALP expression was normalized to the DNA content. Three samples were used per material $(n=3)$.

\subsubsection{Bone-related gene expression}

Bone-related gene expression was evaluated by a quantitative real-time polymerase chain reaction (PCR) assay. RNA isolation was performed using Trizol reagent (Invitrogen) and a Nucleospin RNA isolation kit (Macherey-Nagel GmbH \& Co.) according to the manufacturer's instructions. Total RNA was measured using a NanoDrop spectrophotometer (Nanodrop Technologies, USA). The RNA was used to synthesize complementary DNA with an iScriptcDNA Synthesis kit (BioRad) according to the manufacturer's instructions. PCR analysis was performed with the Bio-Rad realtime PCR system (Bio-Rad, Hercules, CA, USA) on markers for alkaline phosphatase (ALP), collagen type I (Col I), osteocalcin (OCN), Runt-related transcription factor 2 (runx2), bone morphogenetic protein 2 (BMP-2) and osteopontin (OPN), with beta-2 microglobulin (B2M) as the housekeeping gene for normalization. The primer sequences for ALP, Col I, OCN, runx2, BMP-2, OPN and B2M are listed in Table 1. Finally, the real-time PCR reaction was run at $95{ }^{\circ} \mathrm{C}$ for $10 \mathrm{~min}$, followed by $95^{\circ} \mathrm{C}$ for $30 \mathrm{~s}, 60{ }^{\circ} \mathrm{C}$ for $1 \mathrm{~min}$ and $72{ }^{\circ} \mathrm{C}$ for $1 \mathrm{~min}$ for 40 cycles. The data were analyzed using Bio-Rad iQ5 software. The relative amounts of target genes normalized by B2M were calculated by the $2^{-\Delta \mathrm{CT}}$ method, where $\Delta C_{\mathrm{T}}=C_{\mathrm{T}, \text { Target }}-C_{\mathrm{T}, \mathrm{B} 2 \mathrm{M}}$. All conditions evaluated with PCR were cultured in triplo $(n=3)$ as described in section 2.2.2.

\subsubsection{ELISA assay of BMP-2}

The ELISA assay was used to quantify BMP-2 protein production. Samples were rinsed three times with PBS, then $0.2 \mathrm{ml}$ of RIPA buffer (Thermo scientific) was added to each sample, which was kept at $4{ }^{\circ} \mathrm{C}$ for $10 \mathrm{~min}$ and stored at $-80^{\circ} \mathrm{C}$ until further use. The total protein in the cell lysate was measured with the QuantiPro $^{\mathrm{TM}}$ BCA Assay Kit (Sigma, The Netherlands) following the manufacturer's instructions. BMP-2 content in the cell lysate was measured using BMP-2 DuoSet ELISA Development kit (R\&D) according to the manufacturer's instructions. The BMP-2 content was normalized by total protein. All experiments were done in triplicates $(n=3)$.

\subsection{Ectopic bone formation}

To study the influence of microstructure size on osteoinduction, the ceramics were evaluated in an ectopic model in canine. Following the permission of the local animal care committee (Animal Center, Sichuan University, Chengdu, China), the TCP-S and TCP-B granules (1-2 mm, $1.0 \mathrm{cc}$ per implant) were implanted in the paraspinal muscles of eight adult male dogs (mongrel, 10-15 kg) for 12 weeks. All surgeries were conducted under general anesthesia by abdominal injection of sodium pentobarbital (30 mg per $\mathrm{kg}$ body weight) under sterile conditions. Following the surgeries, buprenorphine $(0.1 \mathrm{mg}$ per animal) was given to the animals intramuscularly as pain relief for 2 days, while penicillin $\left(40 \mathrm{mg} \mathrm{kg}^{-1}\right)$ was injected intramuscularly for 3 consecutive days to prevent infection. After operation, the animals were allowed to bear their full weight and received a normal diet. At week 12 the dogs were sacrificed by a celiac injection of an excessive amount of

Table 1

qPCR primer sequences.

\begin{tabular}{lll}
\hline Gene & Forward primer & Reverse primer \\
\hline runx2 & ATGGCGGGTAACGATGAAAAT & ACGGCGGGGAAGACTGTGC \\
OCN & GGCAGCGAGGTAGTGAAGAG & GATGTGGTCAGCCAACTCGT \\
OPN & CCAAGTAAGTCCAACGAAAG & GGTGATGTCCTCGTCTGTA \\
ALP & ACAAGCACTCCCACTTCATC & TTCAGCTCGTACTGCATGTC \\
Col-I & AGGGCCAAGACGAAGACATC & AGATCACGTCATCGCACAACA \\
BMP-2 & GGTAGACCTGTATCGCAGGC & TTTTCCCACTCGTTTCTGGT \\
B2M & GACTTGTCTTTCAGCAAGGA & ACAAAGTCACATGGTTCACA \\
\hline
\end{tabular}


pentobarbital sodium. Implants were harvested with the surrounding tissues, fixed in $4 \%$ formaldehyde and embedded in polymethyl methacrylate after a series of gradient ethanol dehydration. Nondecalcified sections were made by crossing the middle of the explants using a diamond saw (SP-1600, Leica, Germany) and stained with $1 \%$ methylene blue (Sigma) and $0.3 \%$ basic fuchsin (Sigma) solutions. Histological observation was performed using light microscopy. The histological slides were scanned (DIMAGE Scan Elite5400II, model AF5400-2, KONICA MINOLTA) for histomorphometrical analysis and bone formation was quantified as the bone area normalized to the available space using Adobe Photoshop Elements 4.0 software.

\subsection{Statistical analysis}

Multiple comparisons were performed with two-way analysis of variance followed by Bonferroni post-test comparisons. $p$ values of $<0.05$ were considered to be statistically significantly different.

\section{Results}

\subsection{Physical-chemical characterization of TCP-B and TCP-S}

To get target TCP-B ceramic having porosities (both total porosity and microporosity) close to those of TCP-S, TCP-B porous green bodies were sintered at different temperatures (1050, 1100 and $1150{ }^{\circ} \mathrm{C}$ ) for $8 \mathrm{~h}$. As expected from the literature [27], the porosity of TCP-B decreased with sintering temperature, and TCP-B sintered at $1100{ }^{\circ} \mathrm{C}$ had a microporosity close to that of TCP-S (sintered at $1050^{\circ} \mathrm{C}$ ). Thus TCP-S sintered at $1050^{\circ} \mathrm{C}$ and TCP-B sintered at $1100^{\circ} \mathrm{C}$ were the target ceramics subjected to further studies. The XRD patterns of TCP-S and TCP-B showed the two ceramics had the same chemistry (Fig. 1A), being $\beta$-TCP. Different microstructure dimensions were observed by SEM (Fig. 1B and $C)$, with smaller grains and smaller micropores being seen in TCP-S than in TCP-B (Fig. 1B, C). Quantitatively, TCP-S had a grain size of $0.99 \pm 0.20 \mu \mathrm{m}$ and a micropore size of $0.65 \pm 0.25 \mu \mathrm{m}$, while TCP-B displayed larger grain and micropore sizes, of $3.08 \pm 0.52$ and $1.58 \pm 0.65 \mu \mathrm{m}$ respectively. The observed differences in micropore size were confirmed by mercury intrusion results (Fig. 1D), which indicated a micropore range of $0.3-1.3 \mu \mathrm{m}$ with a peak at $0.55 \mu \mathrm{m}$ for TCP-S, while the micropores in TCP-B ranged from 0.8 to $2.2 \mu \mathrm{m}$, with a peak at $1.58 \mu \mathrm{m}$. BET analysis showed a larger specific surface area $\left(1.2 \mathrm{~m}^{2} \mathrm{~g}^{-1}\right)$ in TCP-S than in TCP-B $\left(0.8 \mathrm{~m}^{2} \mathrm{~g}^{-1}\right)$. No difference in total porosity was seen with the mercury intrusion data, with values of 70 and $72 \%$ for TCP-S and TCP-B, respectively. Similar microporosity was obtained for TCP-S and TCP-B (22 and 23\%, respectively).

\subsection{Protein adsorption and ion release}

TCP-S adsorbed a greater amount of proteins than TCP-B at both days 1 and 4 (Fig. 2A), as was expected, since it has a larger surface area. However, protein adsorption did not increase over time for both ceramics. Fig. 2B depicts the results obtained on calcium concentration: in both TCP-S and TCP-B incubation solutions, the calcium concentration was lower compared to BM from day 1 to day 14 , indicating that calcium was not released from the ceramics. A lower calcium concentration was observed in the case of TCP-S than TCP-B, indicating that TCP-S took up a greater amount of calcium ions than TCP-B. Surface changes were not noted for either TCP ceramic, i.e. no apatite layer formation was visible from SEM images on the ceramics' surface after 14 days (Fig. 2C). XRD measurements on the TCP-S samples soaked for 14 days in BM revealed the formation of a new phase $\left(2 \theta=31.8^{\circ}, d\right.$-value $\left.=2.814 \AA\right)$, which is the typical peak of apatite-like calcium phosphates according to
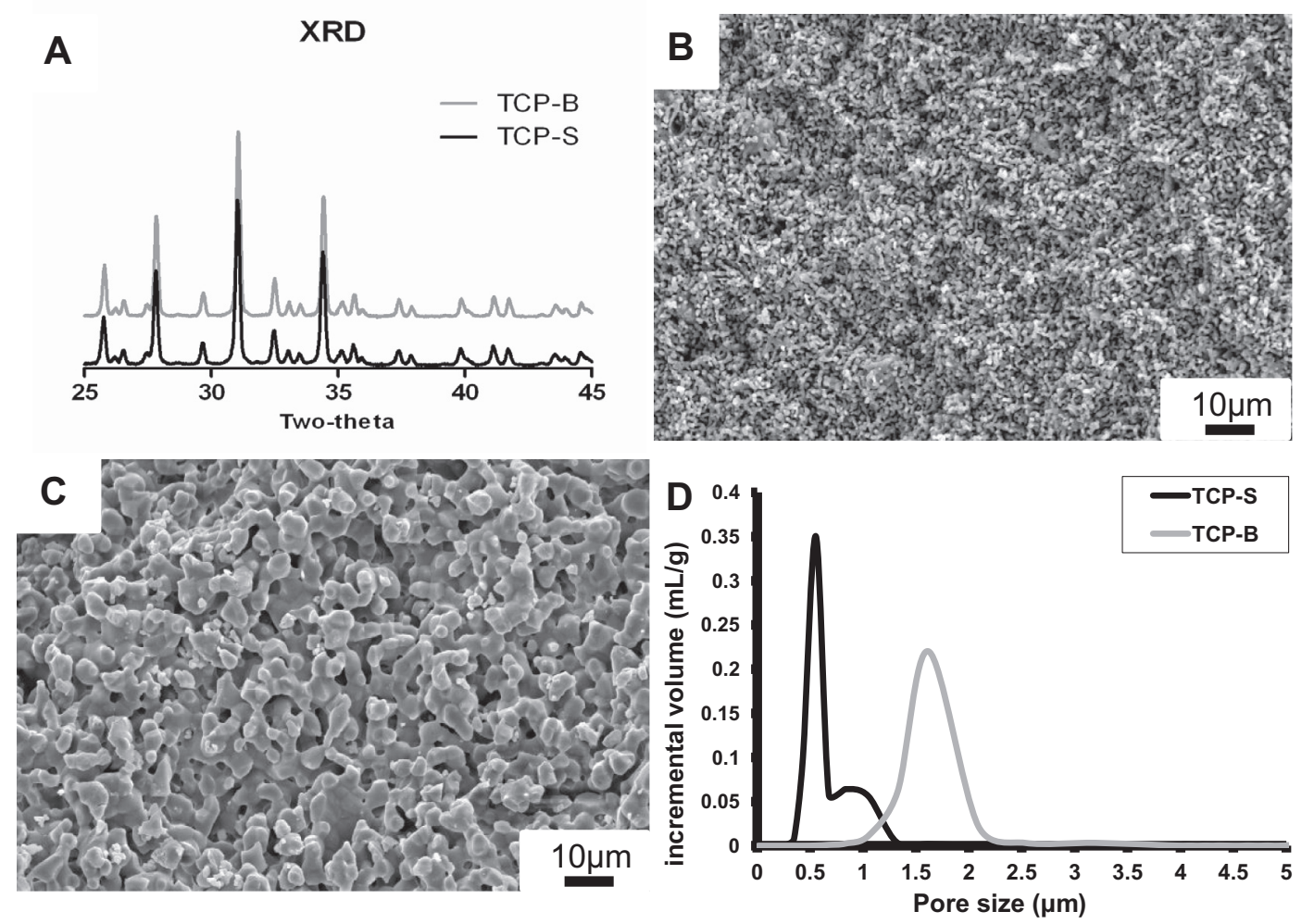

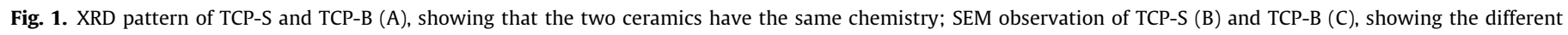
microstructure sizes; micropore distribution of TCP-S and TCP-B (D), the former having smaller micropores than the latter. 
the international standard JCPDS 9-432 (Fig. 2D). Neither this specific XRD peak nor any other could be detected in any of TCPB samples soaked in BM for 2 weeks (Fig. 2B).

\section{3. hBMSC attachment and proliferation}

To evaluate the distribution of hBMSCs on TCP-B and TCP-S surfaces, cells were cultured for 1, 7, 14 and 21 days and stained with methylene blue. As observed by stereomicroscopy, hBMSCs were homogeneously distributed on both TCP-S and TCP-B granules 1 day after cell seeding, and at later time points the staining was more intense (Fig. 3A). These results indicated that both TCP-S and TCP-B ceramics supported hBMSCs attachment, growth and proliferation. Cell proliferation of hBMSCs on TCP-B and TCP-S was further confirmed by DNA quantification (Fig. 3B), as the DNA amount increased from 1 to 21 days on both ceramics. There was no difference in DNA amounts between hBMSCs cultured on TCP-B and TCP-S at day 1, indicating that the number of cells seeded on the two materials was the same. However, on days 14 and 21 more DNA was detected in TCP-S than TCP-B, suggesting that TCP-S enhanced cell proliferation more than TCP-B.

\subsection{Osteogenic differentiation of hBMSCs on the ceramics}

The effect of microstructure size on osteogenic differentiation was evaluated by monitoring the activity of ALP (a marker of early osteogenesis). The specific ALP activity of hBMSCs cultured on TCP$S$ and TCP-B ceramics is shown in Fig. 4, where the ALP content of hBMSCs was normalized to DNA content over time. No changes in
ALP activity of hBMSCs were observed over time on both TCP-S and TCP-B. However, the hBMSCs on TCP-S granules had significantly higher ALP activity than TCP-B at all the time points, indicating an enhanced osteoblastic phenotype of hBMSCs on TCP-S.

\subsection{Bone-related gene expression}

Real-time PCR was used to quantify the expression of osteoblastic genes of Col I, ALP, Runx-2, BMP-2, OPN and OCN (Fig. 5). No changes in the expressions of Runx2, ALP and Col I could be observed from day 7 to day 14 on both materials. While gene expression of Runx2 was increased slightly at days 7 and 14 compared to day 4, ALP and Col I expressions were elevated significantly at days 7 and 14 compared to day 4 on both materials. Significant differences in the gene expressions of Runx2, ALP and Col I were never seen between TCP-S and TCP-B at any time points tested. OCN gene expression increased with time on both materials, and it was significantly higher on TCP-S at day 14 compared to on TCP-B. Similarly, OPN gene expression increased over time on TCP-S, while there was no markedly increase on TCP-B. OPN gene expression was significantly increased by TCP-S at both days 7 and 14. BMP-2 gene expression decreased from day 4 to day 14 , and it was significantly higher for TCP-B at day 4. In line with the latter data, a higher BMP-2 protein level was also seen on TCP-B at day 4 (Fig. 6). The data obtained herein indicated that TCP-S enhanced osteocalcin and osteopontin gene expression in hBMSCs, whereas TCP-B enhanced BMP-2 gene expression and BMP-2 protein production.
A Protein adsorption from basic medium

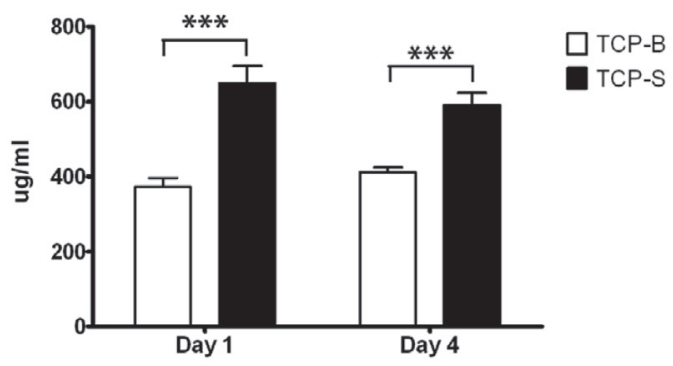

C

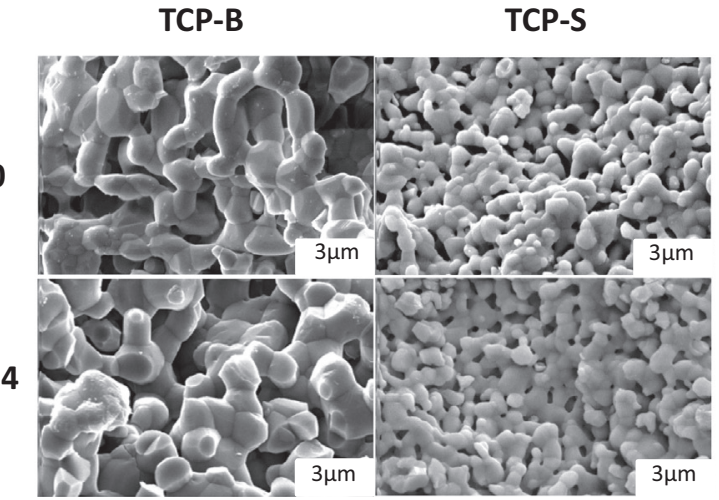

B

$\mathrm{Ca}^{2+}$ amount in the medium

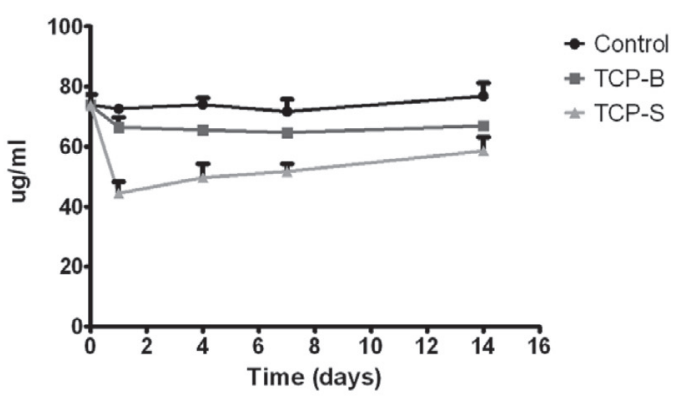

D
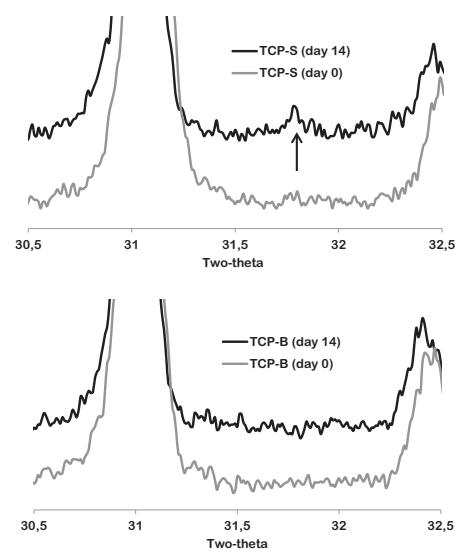

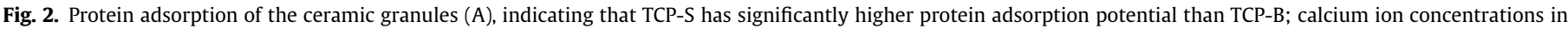

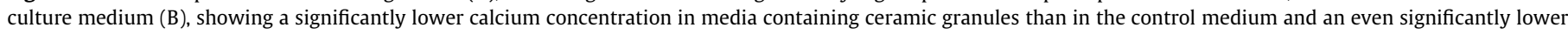

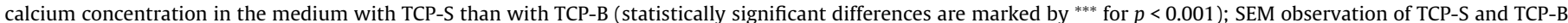

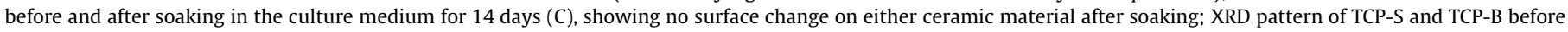
and after soaking in the culture medium for 14 days (D), showing a new typical peak of apatite on TCP-S after a 14 day soaking. 


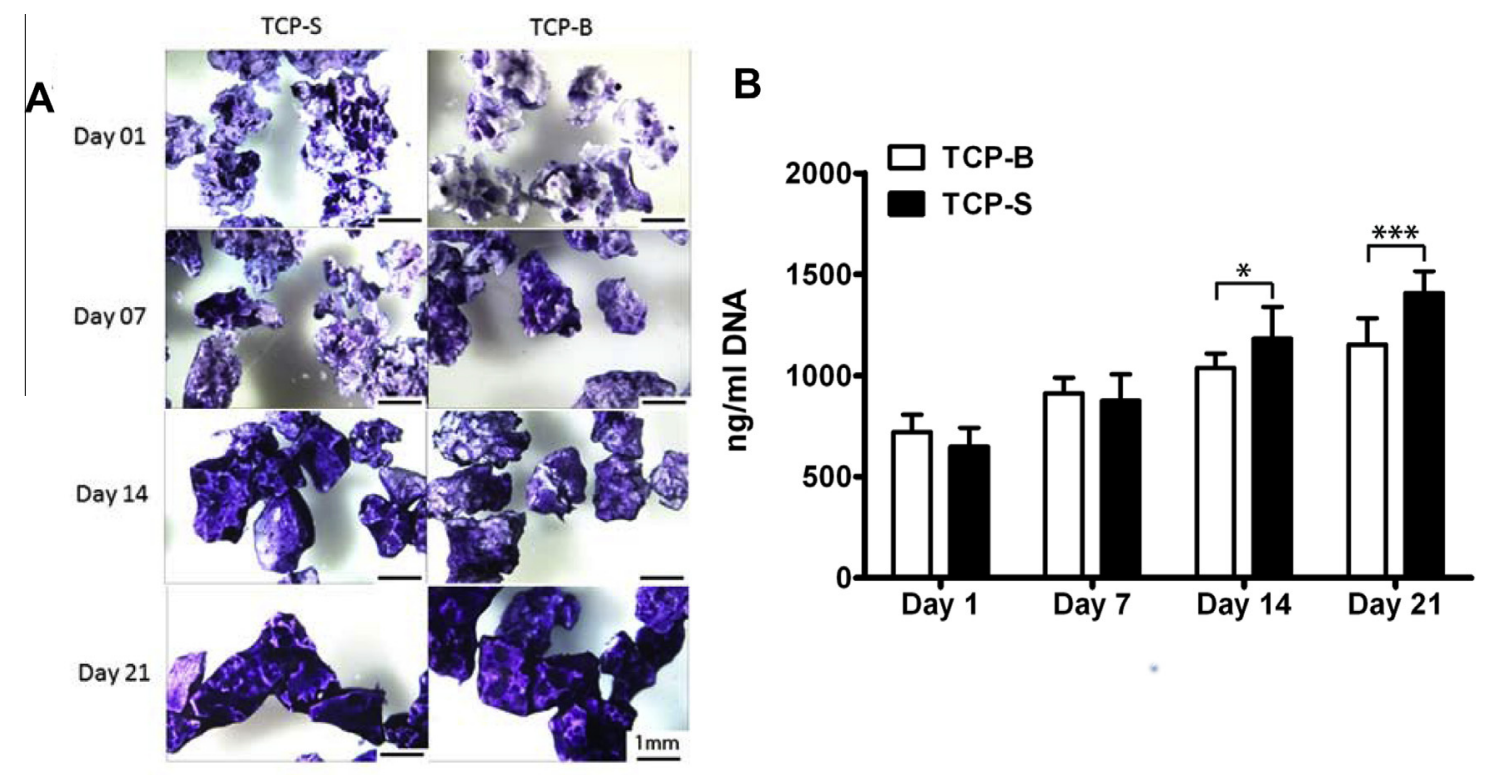

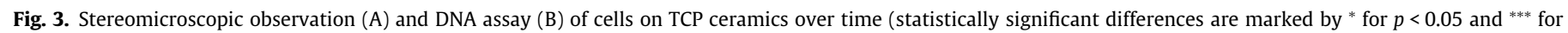
$p<0.001$ ), showing a significantly greater proliferation of hBMSCs on TCP-S.

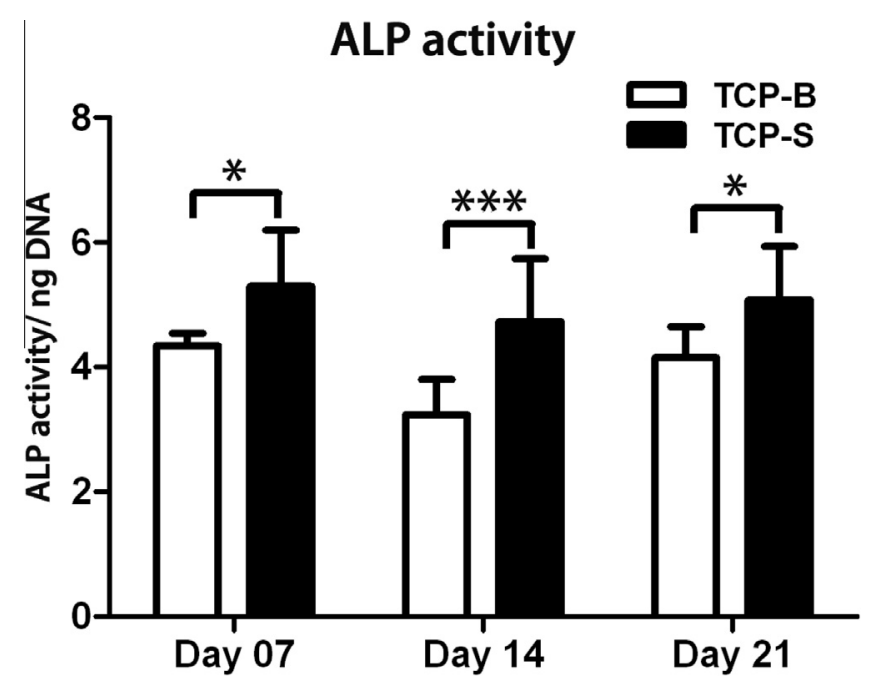

Fig. 4. ALP activity (normalized to DNA) of hBMSCs cultured on TCP ceramic granules (Statistically significant differences are marked by * for $p<0.05$ and ${ }^{* * *}$ for $p<0.001$ ), showing more osteogenic differentiation of hBMSCs on TCP-S than on TCP-B granules.

\subsection{Proliferation and osteogenic differentiation of hBMSCs in trans-well culture}

To distinguish the role of surface topographical cue and chemical changes (e.g. ionic exchange) of the culture medium caused by the microstructure size, hBMSCs were cultured in trans-well plates with ceramics placed on the membrane. The proliferation and ALP activities of hBMSCs on the trans-well plates with both ceramics are shown in Fig. 7. There was a slightly increasing trend in cell number during 14 days of culture, while no differences were found in cell proliferation between the two conditions. The ALP activities of hBMSCs in both conditions increased from day 1 to day 7 and decreased from day 7 to day 14. Importantly, the ALP activity of hBMSCs was significantly greater on the trans-well plates with TCP-B than with TCP-S at days 4 and 7.

\subsection{Ectopic bone formation}

A total of eight samples per TCP ceramic were harvested from eight animals, and were available for histological evaluation and histomorphometry. No bone formation occurred in any of TCP-B samples (Fig. 8A). In contrast, abundant bone formation was formed in all TCP-S explants (Fig. 8B). Closer observations showed the presence of bone inside and between the TCP-S granules (Fig. 8D). The newly formed bone tissue consisted of a mineralized bone matrix with osteocytes inside, and with osteoblasts and osteoclasts on its surface (Fig. 8D). Giant cells were observed in the TCP-S samples (Fig. 8D), indicating cell-mediated resorption of TCP-S. At the same time, only soft tissues were observed in TCP-B and cell-mediated ceramic resorption was not often seen (Fig. 8C). Quantitatively, $21 \pm 10 \%$ of the available space in TCP-S explants was occupied by bone.

\section{Discussion}

Two TCP ceramics having equivalent chemistry and similar microporosity but different microstructure dimensions were prepared. As we hypothesized, the microstructural size has been shown to have a role in determining the osteogenic potential of TCP ceramics both in vitro and in vivo. Osteogenic differentiation of hBMSC was enhanced on TCP-S (smaller microstructure size compared to TCP-B) both at the protein (ALP activity) and gene (OCN and OPN were up-regulated) levels in vitro in the absence of osteogenic factors (e.g. dexamethasone) in the culture medium. In vivo, bone formation was found only in TCP-S, not in TCP-B, in an osteoinduction canine model.

The ectopic bone formation induced by osteoinductive $\mathrm{CaP}$ ceramics suggested that the material could initiate osteogenic differentiation of MSCs. Recent data has shown that BMSCs could be involved in the mechanism of osteoinduction by CaP ceramics [28]. It was shown that BMSCs could migrate from femoral bone to the bioceramic implants through the blood circulation, and contribute to the ectopic bone formation in a canine model. Moreover, it has been previously shown that hBMSCs display different cellular behavior according to the ceramic properties in vitro [12,29]. 

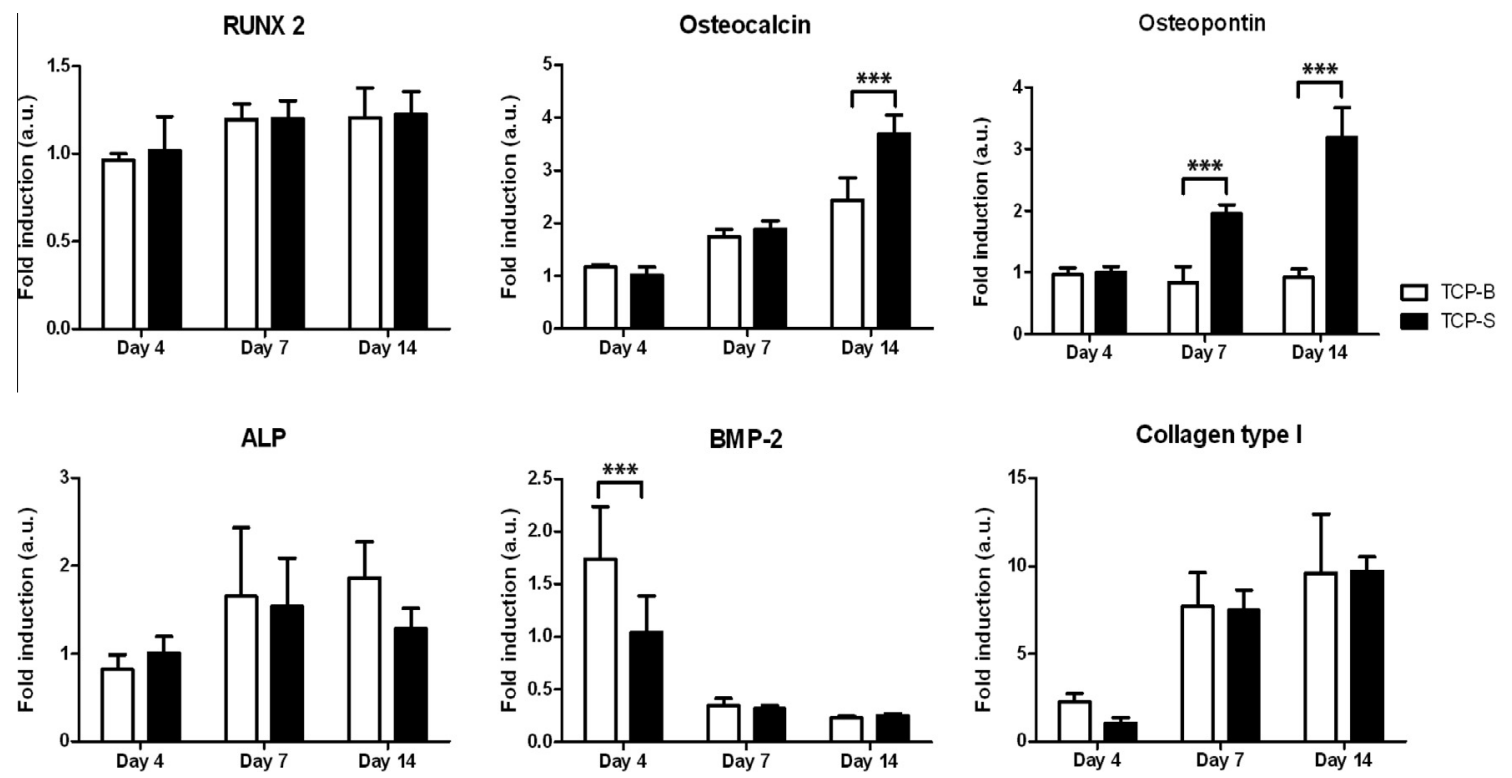

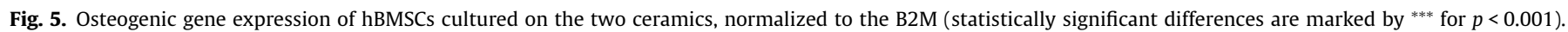

\section{BMP-2/ total protein}

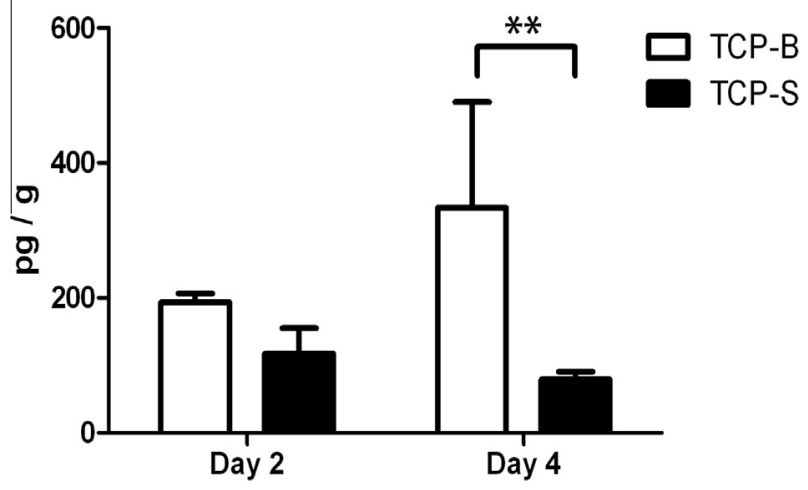

Fig. 6. ELISA assay of BMP-2 produced by hBMSCs cultured on ceramic granules (statistically significant difference is marked by ${ }^{* *}$ for $p<0.01$ ), indicating a higher level of BMP-2 production in the case of TCP-B than in the case of on TCP-S after 4 days.

Therefore, examining the cellular behavior of hBMSCs cultured on TCP-S and TCP-B ceramics in vitro may provide insights into how MSCs respond to osteoinductive CaP ceramic in vivo to form bone.
In vitro, the results of q-PCR analysis showed that hBMSCs cultured on TCP-S granules exhibited higher expression of OCN at day 14 and OPN at days 7 and 14 (Fig. 5). OCN is an established indicator of osteoblastic differentiation of hBMSCs and is synthesized only by mature osteoblasts, cementoblasts and odontoblasts to bind both collagen and calcium in the ECM of bone tissue [30]. OPN is highly expressed in bone, and its expression is increased during osteoblastic differentiation of hBMSCs [26]. ALP is a cell surface glycoprotein, and is the most widely recognized marker of osteoblastic differentiation. In this study, we used ALP/DNA to express the ALP activity per cell to characterize osteogenic differentiation corrected to cell numbers. The hBMSCs grown on the surface of TCP-S showed higher levels of ALP activity. Taken together, these results suggested that TCP-S induced hBMSCs to differentiate into osteogenic cells better than TCP-B without soluble osteogenic factors in the medium.

In vivo, an intramuscular implantation in a canine model was used to determine the osteoinductive potential of the two materials. Histologically, abundant newly formed bone was observed in TCP-S scaffolds, but no bone formation occurred in TCP-B implants after 12 weeks. So far, the underlying mechanism for osteoinduction is not yet fully understood. However, some previously proposed mechanisms could help to explain why, in this study, the smaller microstructural size was effective at inducing osteogenic differentiation in vitro and bone formation in vivo.
A

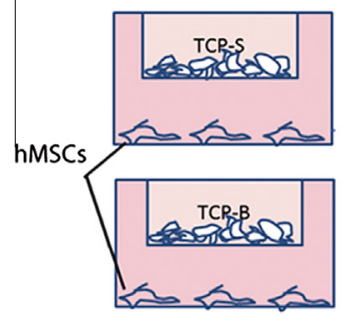

B

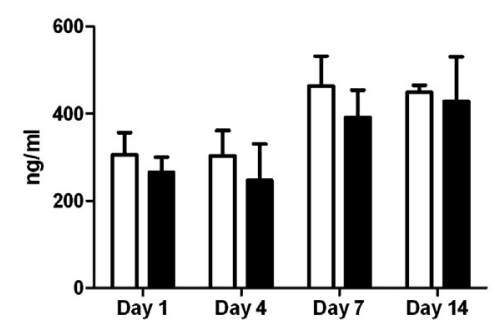

C

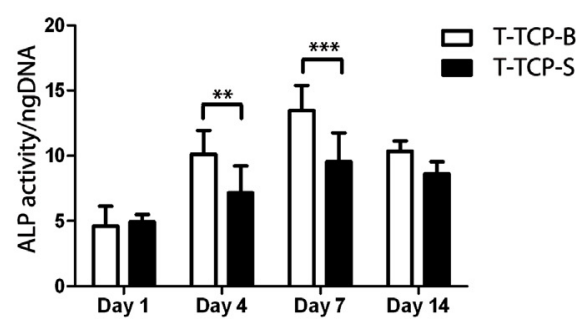

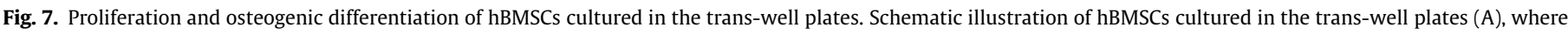

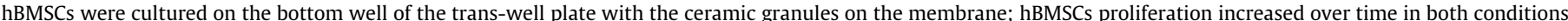

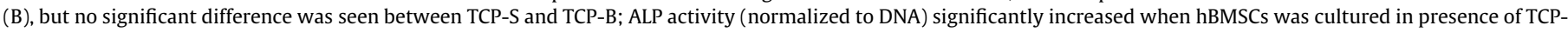
$\mathrm{B}(\mathrm{C})$ (statistically significant differences are marked by ${ }^{* *}$ for $p<0.05$ and ${ }^{* * *}$ for $p<0.001$ ). 

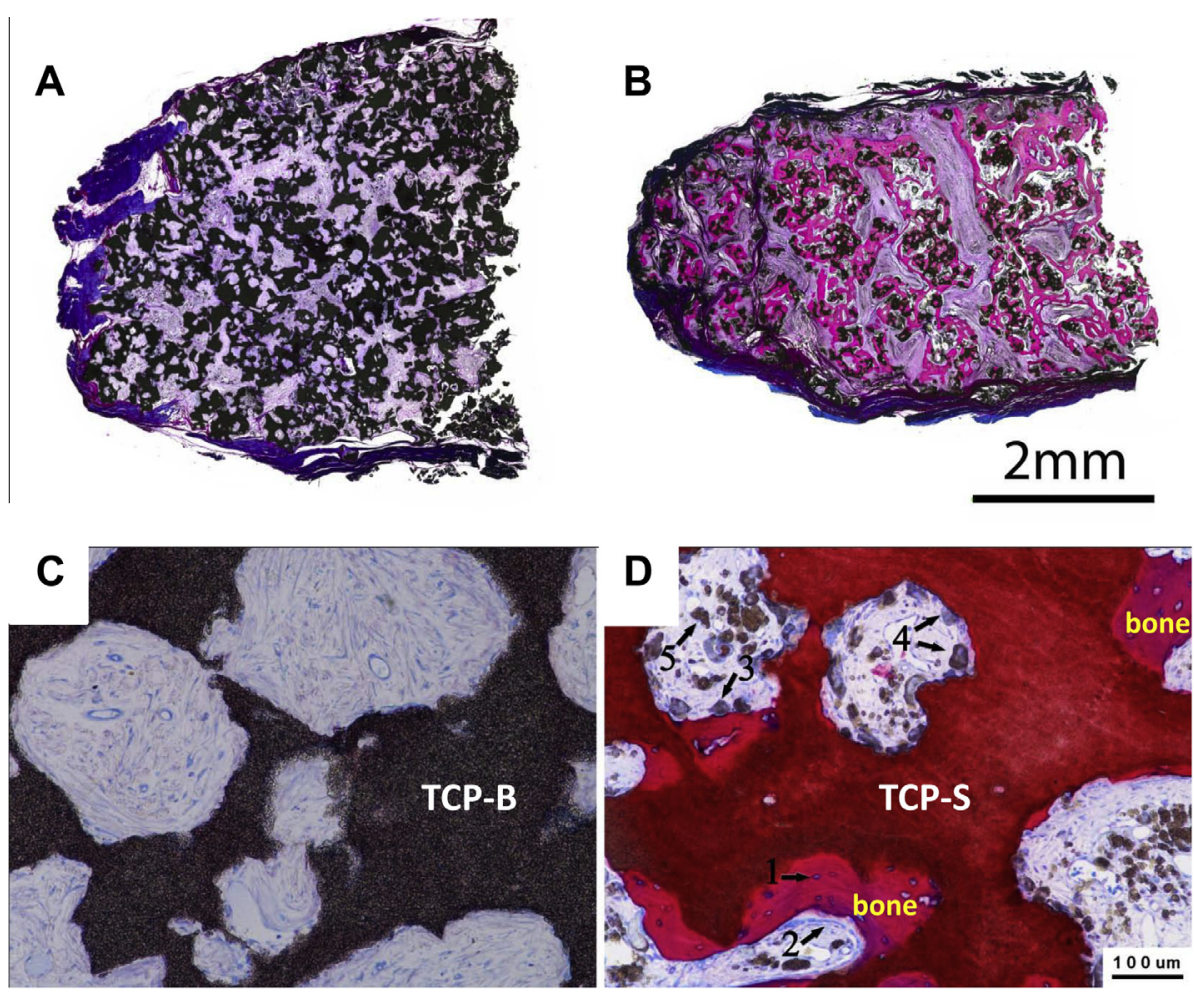

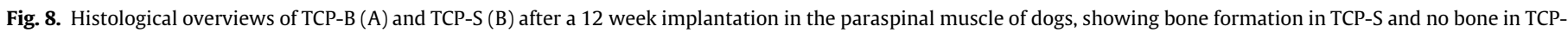

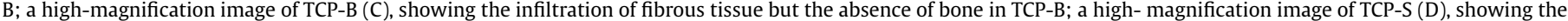

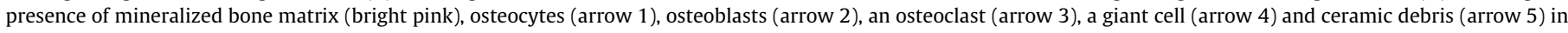
TCP-S.

Protein adsorption has long been suggested to play an important role in the osteoinduction of CaP ceramics. BMPs (e.g. BMP-2) are dose-dependent bone-forming growth factors [31]. It has been emphasized that CaP ceramics first concentrate BMPs from body fluids and then induce bone formation [7,32]. In this study, TCP-S enhanced osteogenic differentiation of hBMSCs in the absence of growth factors such as BMPs in the culture medium. However, the role of protein adsorption in osteoinduction could not be excluded, since such growth factors exist in vivo. Given the same microporosity, the decreased micropore size increased the surface area, leading to improved protein adsorption of TCP-S (Fig. 2A). hBMSCs may be sensitive not only to the adsorbed osteogenic growth factors, but also to non-osteogenic growth factors (e.g. fibronectin and vitronectin in serum) that induce osteogenic differentiation via, for instance, a focal adhesion process, which in turn could trigger osteogenic differentiation of stem cells, possibly via mechanotransduction [22]. Besides this, with the presence of osteogenic growth factors in vivo, TCP-S would concentrate a greater amount of growth factors, and thus further enhance osteogenic differentiation of MSCs infiltrating into the implants to form bone, compared to TCP-B.

Several studies have shown the role of topographical cues in stem cell differentiation towards a desired direction for tissue regeneration and cell therapy [33-35]. Importantly, on certain scales and with certain shapes, nano- or microstructures have triggered osteogenic differentiation of hBMSCs in vitro without osteogenic factors (e.g. dexamethasone) in the culture medium [13]. With the same microporosity but with smaller microstructural size, TCP-S enhanced osteogenic differentiation of hBMSC more than TCP-B. However, it is currently a challenge to distinguish the role of protein adsorption and topographic cues created by surface topography in the biological responses of a material.

It is assumed that the release of $\mathrm{Ca}^{2+}$ ions from the materials is an important factor in inducing bone formation. In this study, it was expected that, with a larger surface area, TCP-S would release a greater amount of $\mathrm{Ca}^{2+}$ into the culture medium and thus enhance osteogenic differentiation of hBMSC in vitro. Instead, we observed a decrease in $\mathrm{Ca}^{2+}$ concentration with both ceramics (Fig. 2B), suggesting uptake of $\mathrm{Ca}^{2+}$ from the culture medium. The decrease in $\mathrm{Ca}^{2+}$ in the culture medium may be a result of the precipitation of calcium/phosphate onto the ceramic surface, where it could form an apatite layer that would enhance the osteogenic differentiation of MSCs, as assumed by the literature $[17,36]$. We observed that the amount of $\mathrm{Ca}^{2+}$ in the medium with TCP-S was significantly lower than in the medium with TCP-B $(p<0.001)$ (Fig. 2B). XRD measurements on the TCP-S samples soaked for 14 days in BM revealed the formation of a new phase, identified as a typical apatite-like calcium phosphate according to the international standard JCPDS 9-432 (Fig. 2D). This new peak indicates that calcium ions may have precipitated onto the surface of TCP-S, leading to a slight increase in the $\mathrm{Ca} / \mathrm{P}$ ratio of TCP-S. However, this peak was not detectable in any of the TCP-B samples soaked in BM for 14 days, most likely due to the limited amount of calcium adsorbed by TCP-B from the BM (Fig. 2B). However, the formation of an apatite layer was not observed by SEM on the surface of both ceramics, suggesting that the amount of $\mathrm{Ca}^{2+}$ adsorbed by the surface of the two materials could have been not sufficient to trigger a visible apatite layer (Fig. 2C). Our previous work showed that, when soaking $\beta$-TCP in protein-free medium (i.e. $\alpha$-MEM alone), abundant precipitation of calcium in the form of an apatite layer on its surface occurred and was visible by SEM. Conversely, no apatite layer formation occurred when $\beta$-TCP was immersed in medium containing proteins (i.e. basic medium) [29], similarly to what we observed in this study. Other studies confirm that increasing amounts of serum have increasing inhibitory effects on the formation of an apatite layer on biomaterials $[37,38]$. 
In the trans-well plate culture, a higher ALP activity of hBMSC was observed in the case of TCP-B. This result is in line with previously published results, where a high extracellular $\mathrm{Ca}^{2+}$ concentration was reported to enhance osteogenic differentiation of hBMSCs [26]. It could well be that the higher local calcium concentration on the TCP-S surface enhanced the osteogenic differentiation of hBMSC in this study when cells were cultured directly on the TCP ceramics. Taken together, the results indicate that the direct contact of cells with the material's surface is necessary for osteogenic differentiation of MSC to occur in TCP-S. This indication is supported by the observation that ectopic bone formation induced by CaP ceramics always starts on the material's surface [39].

BMPs (e.g. BMP-2 and BMP-7) were detected in cells involved in bone morphogenesis initiated by osteoinductive CaP ceramics $[40,41]$ while, in this study, BMP-2 was enhanced more at both the gene and protein levels in hBMSCs cultured on TCP-B than in those cultured on TCP-S. With the protein production of BMP-2 by hBMSCs cultured on TCP-B, we may expect osteoinduction in TCP-B as well. However, since BMP induces bone formation in a dose-dependent manner [31], the amount of BMP-2 produced may not be enough to induce the bone formation in the case of TCP-B indicated by the current result.

Being the main inorganic components of hard tissues, CaP ceramics are often considered as promising bone grafting materials because of their biocompatibility, bioactivity and resorbability. The influence of chemistry on the properties of CaP ceramics has been evaluated often. For instance, various studies on the influence of chemistry (e.g. the ratio of TCP to HA) on the resorption rate has helped the fabrication of CaP ceramics with desired resorption rates $[12,20,42]$. As histologically observed in the current study, the resorption rate differed between the two ceramics, with a clear cell-mediated resorption in TCP-S. The delayed resorption of TCP-B might be caused by its smaller surface area, which limits the chemical dissolution of the ceramic [20]. It could also be because of the influence of surface topography on the phagocytes involved in cell-mediated resorption of materials (e.g. macrophages) $[3,43]$. We observed that osteopontin was upregulated in hBMSCs on TCP-S. The important role osteopontin plays in anchoring osteoclasts to the extracellular matrix has been shown [44]; therefore, the cell-mediated resorption and osteoinduction of TCP-S may be coupled. Responding to the surface microstructure of TCP-S, hBMSCs may undergo osteogenic differentiation to form bone and, at the same time, produce osteopontin, which induces osteoclast-like cells to resorb TCP-S. This finding may explain the previous observation that, even though TCP is generally considered to be a resorbable material, it was not resorbed at all in some studies where TCP ceramics with large grains were used [45].

The current findings suggest that the small size of the surface microstructure of TCP-S may provide a suitable local environment for osteoinduction to occur. It could concentrate ions to form apatite-like calcium phosphate and proteins (e.g. growth factors) or provide topographic cues, thereby determining the spatial regulation of proliferation and osteogenic differentiation of MSCs on the surface. The careful design of materials to distinguish the roles of ion release, protein adsorption and physical cues in osteoinduction of CaP ceramics will be the subject of future studies.

Microstructural modification, previously achieved by varying the microporosity [46] and now by adjusting the microstructure size, could render CaP ceramics osteoinductive and more resorbable. Such a finding would encourage further optimization of $\mathrm{CaP}$ ceramics for bone regeneration in the challenge to replace autologous bone in clinics.

\section{Conclusion}

Given the same microporosity and chemistry, the microstructural size affects the bone-forming ability of TCP ceramics. A small microstructure is suggested as the best scale for ectopic bone formation in this study. hBMSCs are sensitive to the local environment created by the surface microstructure and undergo osteogenic differentiation in the absence of osteogenic growth factors in vitro. Although the mechanism is not fully understood, the current data partially explain how MSCs may respond to the surface microstructure to form bone.

\section{Acknowledgements}

The authors gratefully acknowledge the Fund of the China Scholarship Council for supporting J.Z. Special thanks are due to Paul Wieringa, Bach Quang Le and Lorenzo Moroni for their technical expertise and useful discussion.

\section{Appendix A. Figures with essential colour discrimination}

Certain figures in this article, particularly Figs. 3, 7 and 8, are difficult to interpret in black and white. The full colour images can be found in the on-line version, at http://dx.doi.org/10.1016/ j.actbio.2014.03.021.

\section{References}

[1] Phillips J, Forrest C, Gruss J. Current concepts in the use of bone grafts in facial fractures. Basic science considerations. Clin Plast Surg 1992;19:41-58.

[2] Lan Levengood SK, Polak SJ, Wheeler MB, Maki AJ, Clark SG, Jamison RD, et al, Multiscale osteointegration as a new paradigm for the design of calcium phosphate scaffolds for bone regeneration. Biomaterials 2010;31:3552-63.

[3] Okuda T, Ioku K, Yonezawa I, Minagi H, Kawachi G, Gonda Y, et al. The effect of the microstructure of $\beta$-tricalcium phosphate on the metabolism of subsequently formed bone tissue. Biomaterials 2007;28:2612-21.

[4] Faour O, Dimitriou R, Cousins CA, Giannoudis PV. The use of bone graft substitutes in large cancellous voids: any specific needs? Injury 2011;42:S87-90.

[5] Burchardt H, Glowczewskie Jr F, Enneking W. The effect of adriamycin and methotrexate on the repair of segmental cortical autografts in dogs. J Bone Joint Surg Am 1983;65:103-8.

[6] Damien CJ, Parsons JR. Bone graft and bone graft substitutes: a review of current technology and applications. J Appl Biomater 1991;2:187-208.

[7] Yang Z, Yuan H, Tong W, Zou P, Chen W, Zhang X. Osteogenesis in extraskeletally implanted porous calcium phosphate ceramics: variability among different kinds of animals. Biomaterials 1996;17:2131-7.

[8] Bohner M, Gbureck U, Barralet J. Technological issues for the development of more efficient calcium phosphate bone cements: a critical assessment. Biomaterials 2005;26:6423-9.

[9] Barradas AMC, Yuan H, van Blitterswijk CA, Habibovic P. Osteoinductive biomaterials: current knowledge of properties, experimental models and biological mechanisms. Eur Cell Mater 2011;21:407-29.

[10] Habibovic P, Van der Valk C, Van Blitterswijk C, De Groot K, Meijer G. Influence of octacalcium phosphate coating on osteoinductive properties of biomaterials. J Mater Sci Mater Med 2004;15:373-80.

[11] Yuan H, Van Blitterswijk C, De Groot K, De Bruijn J. A comparison of bone formation in biphasic calcium phosphate (BCP) and hydroxyapatite (HA) implanted in muscle and bone of dogs at different time periods. J Biomed Mater Res Part A 2006;78:139-47.

[12] Yuan H, Fernandes H, Habibovic P, De Boer J, Barradas A, De Ruiter A, et al. Osteoinductive ceramics as a synthetic alternative to autologous bone grafting. Proc Natl Acad Sci 2010;107:13614-9.

[13] Oh S, Brammer KS, Li Y, Teng D, Engler AJ, Chien S, et al. Stem cell fate dictated solely by altered nanotube dimension. Proc Natl Acad Sci 2009;106:2130-5.

[14] Ripamonti U, Richter PW, Thomas ME. Self-inducing shape memory geometric cues embedded within smart hydroxyapatite-based biomimetic matrices. Plast Reconstr Surg 2007;120:1796-807.

[15] Curtis A, Wilkinson C. Nantotechniques and approaches in biotechnology. Trends Biotechnol 2001;19:97-101.

[16] Galli C, Piemontese M, Lumetti S, Manfredi E, Macaluso G, Passeri G. The importance of WNT pathways for bone metabolism and their regulation by implant topography. Eur Cells Mater 2012;24:46-59.

[17] Habibovic P, Sees TM, van den Doel MA, van Blitterswijk CA, de Groot K. Osteoinduction by biomaterials - physicochemical and structural influences. J Biomed Mater Res Part A 2006;77:747-62. 
[18] Yamasaki H, Sakai H. Osteogenic response to porous hydroxyapatite ceramics under the skin of dogs. Biomaterials 1992;13:308-12.

[19] Yuan H, Kurashina K, de Bruijn JD, Li Y, De Groot K, Zhang X. A preliminary study on osteoinduction of two kinds of calcium phosphate ceramics. Biomaterials 1999;20:1799-806.

[20] Habibovic P, Yuan H, Van Der Valk CM, Meijer G, Van Blitterswijk CA, De Groot K. 3D microenvironment as essential element for osteoinduction by biomaterials. Biomaterials 2005;26:3565-75.

[21] Urist MR, Huo YK, Brownell AG, Hohl WM, Buyske J, Lietze A, et al. Purification of bovine bone morphogenetic protein by hydroxyapatite chromatography. Proc Natl Acad Sci 1984;81:371-5.

[22] Guilak F, Cohen DM, Estes BT, Gimble JM, Liedtke W, Chen CS. Control of stem cell fate by physical interactions with the extracellular matrix. Cell Stem Cell 2009;5:17-26.

[23] Fu J, Wang YK, Yang MT, Desai RA, Yu X, Liu Z, et al. Mechanical regulation of cell function with geometrically modulated elastomeric substrates. Nat Methods 2010;7:733-6.

[24] McBeath R, Pirone DM, Nelson CM, Bhadriraju K, Chen CS. Cell shape, cytoskeletal tension, and RhoA regulate stem cell lineage commitment. Dev Cell 2004;6:483-95.

[25] Kilian KA, Bugarija B, Lahn BT, Mrksich M. Geometric cues for directing the differentiation of mesenchymal stem cells. Proc Natl Acad Sci 2010;107:4872-7.

[26] Barradas A, Fernandes HA, Groen N, Chai YC, Schrooten J, van de Peppel J, et al. A calcium-induced signaling cascade leading to osteogenic differentiation of human bone marrow-derived mesenchymal stromal cells. Biomaterials 2012;33:3205-15.

[27] Daculsi G, Aguado E, Goyenvalle E, LeGeros RZ, LeGeros JP, Grimandi G, et al. Effect of sintering process of HA/TCP bioceramics on microstructure, dissolution, cell proliferation and bone ingrowth. Key Eng Mater 2008;361:1139-42.

[28] Song G, Habibovic P, Bao C, Hu J, van Blitterswijk CA, Yuan H, et al. The homing of bone marrow MSCs to non-osseous sites for ectopic bone formation induced by osteoinductive calcium phosphate. Biomaterials 2013;34:2167-76.

[29] Barradas AM, Monticone V, Hulsman M, Danoux C, Fernandes H, Tahmasebi Z, et al. Molecular mechanisms of biomaterial-driven osteogenic differentiation in human mesenchymal stromal cells. Integr Biol 2013;5:920-31.

[30] Sun H, Wu C, Dai K, Chang J, Tang T. Proliferation and osteoblastic differentiation of human bone marrow-derived stromal cells on akermanitebioactive ceramics. Biomaterials 2006;27:5651-7.

[31] Yasko AW, Lane J, Fellinger E, Rosen V, Wozney J, Wang E. The healing of segmental bone defects, induced by recombinant human bone morphogenetic protein (rhBMP-2). A radiographic, histological, and biomechanical study in rats. J Bone Joint Surg Am 1992;74:659-70.
[32] Ripamonti U. Osteoinduction in porous hydroxyapatite implanted in heterotopic sites of different animal models. Biomaterials 1996;17:31-5.

[33] Dalby MJ, Gadegaard N, Tare R, Andar A, Riehle MO, Herzyk P, et al. The control of human mesenchymal cell differentiation using nanoscale symmetry and disorder. Nat Mater 2007;6:997-1003.

[34] Gittens RA, McLachlan T, Olivares-Navarrete R, Cai Y, Berner S, Tannenbaum R, et al. The effects of combined micron-/submicron-scale surface roughness and nanoscale features on cell proliferation and differentiation. Biomaterials 2011;32:3395-403.

[35] Guvendiren M, Burdick JA. The control of stem cell morphology and differentiation by hydrogel surface wrinkles. Biomaterials 2010;31:6511-8.

[36] Fujibayashi S, Neo M, Kim H-M, Kokubo T, Nakamura T. Osteoinduction of porous bioactive titanium metal. Biomaterials 2004;25:443-50.

[37] Marques P, Serro A, Saramago B, Fernandes A, Magalhaes M, Correia R. Mineralisation of two phosphate ceramics in HBSS: role of albumin. Biomaterials 2003;24:451-60.

[38] Garnett J, Dieppe P. The effects of serum and human albumin on calcium hydroxyapatite crystal growth. Biochem J 1990;266:863-8.

[39] Yuan H, Yang Z, Li Y, Zhang X, De Bruijn J, De Groot K. Osteoinduction by calcium phosphate biomaterials. J Mater Sci Mater Med 1998;9:723-6.

[40] Duneas N, Crooks J, Ripamonti U. Transforming growth factor- $\beta 1$ : induction of bone morphogenetic protein genes expression during endochondral bone formation in the baboon, and synergistic interaction with osteogenic protein-1 (BMP-7). Growth Factors 1998;15:259-77.

[41] Ripamonti U, Heliotis M, Rueger D, Sampath T. Induction of cementogenesis by recombinant human osteogenic protein-1 (hOP-1/BMP-7) in the baboon (Papio ursinus). Arch Oral Biol 1996;41:121-6.

[42] Yamada S, Heymann D, Bouler J-M, Daculsi G. Osteoclastic resorption of calcium phosphate ceramics with different hydroxyapatite/ $\beta$-tricalcium phosphate ratios. Biomaterials 1997; 18:1037-41.

[43] Pirraco R, Reis R, Marques A. Effect of monocytes/macrophages on the early osteogenic differentiation of hBMSCs. J Tissue Eng Regen Med 2012;7:392-400

[44] Merry K, Dodds R, Littlewood A, Gowen M. Expression of osteopontin mRNA by osteoclasts and osteoblasts in modelling adult human bone. J Cell Sci 1993;104:1013-20.

[45] Handschel J, Wiesmann HP, Stratmann U, Kleinheinz J, Meyer U, Joos U. TCP is hardly resorbed and not osteoconductive in a non-loading calvarial model. Biomaterials 2002;23:1689-95.

[46] Campion CR, Chander C, Buckland T, Hing K. Increasing strut porosity in silicate-substituted calcium-phosphate bone graft substitutes enhances osteogenesis. J Biomed Mater Res B Appl Biomater 2011;97:245-54. 